\title{
Q\&A: Joanna Cole on writing science books for kids
}

\author{
Joanna Cole has authored more than 100 science books for children, including the best-selling Magic School \\ Bus series, the latest edition of which tackles the topic of climate change. In the last of our series of interviews \\ with authors who write science books for different audiences, Cole reveals how clarity and colour can \\ introduce even very young children to science.
}

\begin{abstract}
Why did you decide to write about science for children?

I have always loved to read about science. I decided to write science books for children 40 years ago. My first book was about cockroaches. And I was also writing little humorous story books. When [the publisher] Scholastic wanted to do some science books that kids would really like, they called me. In 1986 we started the Magic School Bus series, which is full of science but also has a story and humour.

\section{Where do you start?}

When I write a science book, I want it to be about concepts and ideas, rather than just a stack of facts. Science is not a bunch of vocabulary words that kids are supposed to memorize - it is about discovery and connections. I always start by thinking about a central question, and then try to answer that question.
\end{abstract}

\section{How important are illustrations and layout?}

In children's books, editors usually like to keep authors and illustrators apart - they don't want any trouble, or for people to offend each other. But illustrator Bruce Degen and I worked together, and it was wonderful. In 1986, children's books were much more traditional and staid. I remember being a little worried that I would sully my reputation with these books. But they were so much fun that I wrote them anyway. I would make a dummy out of typewriter paper, and print the words out from my computer, draw word balloons, and stick everything onto the page with tape. The first reaction from the sales representatives was that the books were too cluttered. But that's what kids like about them.

\section{Do you do a lot of research?}

I research for maybe half a year, so I learn a lot. I read journal articles, textbooks and popular science. You have to know a lot more than what ends up on the page. And you have to try to make it as accessible as possible. I once wrote some articles for adults in a magazine and I was amazed at how easy

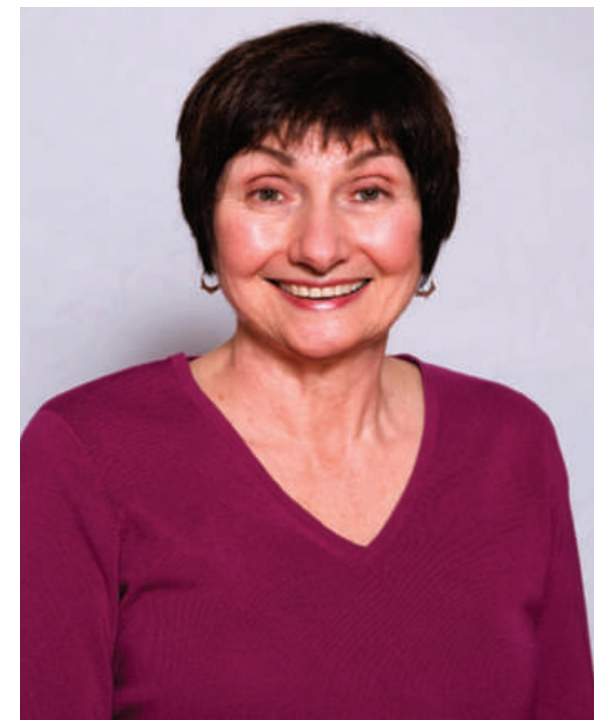

Joanna Cole: writing for kids is a public service.

it was - you don't have to rewrite everything to make it clearer and simpler and still accurate. Once a book is written I send it to a scientist for checking, and we make changes accordingly.

\section{Has the children's book market changed over the years?}

In the 1980s, the main market was schools and libraries. These days it is more direct to book stores. Colour printing has become affordable, and there was a big promotion in the United States to get people to read to their kids in the home, so there has been a boom in trade books. School libraries are very conscientious about having books of all kinds. The trade books are more what the parents and grandparents will buy - more on popular topics such as the Solar System and fewer on less saleable subjects. I don't think I could sell a book on cockroaches today.

The latest Magic School Bus book, released this week, is about the climate challenge. Why did you pick this topic? The publisher said that they wanted to do a bunch of controversial subjects. I decided to do climate change first because I thought it was so urgent.
What ages of kids read your books? When I write, I think of third and fourth graders [8- and 9-year-olds], but amazingly, people read the books to their 2-year-olds. When they're young, you can pick and choose which bits to read. Then when they come back to it when they're older, they find a whole other level. Teachers embraced the books very early on, and started using them in their science curriculum as a jumping-off point.

\section{Do your books inspire children to go into science?}

Perhaps they have. When we sign books, the kids often say that they are going to be a scientist. It is an important public service to write science books.

\section{Is writing for kids profitable?}

I never expected to make a living as a children's book writer. I found out that I could make a living but only by working very, very hard and writing lots of books and magazine articles. Of course, the Magic School Bus series is a whole other story, it has sold millions.

\section{How should a researcher who would like to write kids' books get started?}

Don't pair up with an illustrator first as the publisher wants to choose the illustrator themselves. Today, publishers don't read unsolicited manuscripts - people send their stuff to agents. Associations such as the Society of Children's Book Writers and Illustrators have meetings worldwide. Writers who want to be published can go to these meetings and meet editors and agents.

\section{Should more scientists be writing for children?}

They can if they want to, but it's as important for them to do science. What would we do without scientists?

Interview by Nicola Jones, a commissioning editor for Nature's Opinion section.

\footnotetext{
Joanna Cole's latest book is The Magic School Bus and the Climate Challenge (Scholastic, 2010).

For more on how to write science books for different audiences, see go.nature.com/WvnBnn.
} 